\author{
Aleksander I. Zyrianow \\ Andriej Ju. Koroliow \\ Swietłana E. Myszliawcewa \\ Azat A. Safarian \\ Permski Państwowy Narodowy Uniwersytet Badawczy, Perm (Rosja)
}

\title{
PROPOZYCJE ZAGOSPODAROWANIA PRZESTRZENI NA POTRZEBY TURYSTYKI AKTYWNEJ NA URALU W KRAJU PERMSKIM
}

\begin{abstract}
Abstrakt: Położony w południowym Uralu kraj permski oprócz surowców mineralnych i rozwiniętego przemysłu poszczycić się może także rozległymi obszarami, na których można rozwijać turystykę aktywną i specjalistyczną, w tym mającą cechy sportu amatorskiego. Rozwój tego rodzaju form turystyki wymaga często dużych nakładów związanych z przystosowaniem przestrzeni do realizacji różnych typów aktywności. Wymaga także korelacji między określonym charakterem przestrzeni oraz preferowaną formą turystyki, co często doprowadza do konfliktów środowiskowych między rozwojem turystyki a ochroną środowiska przyrodniczego. W artykule zaprezentowano najważniejsze elementy potencjału turystycznego Kraju Permskiego oraz możliwości rozwoju turystyki sportowej w kontekście rzeczywistych i potencjalnych konfliktów środowiskowych.
\end{abstract}

Słowa kluczowe: turystyka aktywna, turystyka sportowa, zagospodarowanie turystyczne, Ural, Kraj Permski, ochrona przyrody.

\section{WPROWADZENIE}

Stwierdzenie, że obszary o wybitnych walorach przyrodniczych powinny być racjonalnie wykorzystywane w turystyce, a także chronione przed innymi, szczególnie „nieekologicznymi” rodzajami działalności, jest banalne i w obecnych czasach powszechnie przyjęte $\mathrm{w}$ świecie. Dotyczy to przede wszystkim unikatowych i pięknych przyrodniczo miejsc. Takie obszary powinny mieć określony system organizacji w postaci parków narodowych, krajobrazowych i innych form stymulowania działalności turystycznej, łączących funkcje ochrony przyrody i rozwoju turystyki. Wiele państw odniosło $\mathrm{w}$ tej dziedzinie sukces, tworząc ogólnokrajowe sieci parków narodowych.

W Rosji jednakże działanie takie zawsze odbiegało od potrzeb ludności w zakresie organizacji turystyki i wypoczynku w środowisku naturalnym ze względu na przesunięcie priorytetów $\mathrm{w}$ stronę ochrony dziedzictwa naturalnego przed wszelkimi rodzajami działalności gospodarczej, w tym także rekreacyjnej i turystycznej. Zwieńczeniem powstałego w Rosji systemu ochrony przyrody są rezerwaty. Zgodnie z klasycznym rozumieniem pojęcia ochrony i rezerwatów przy- rody, sformułowanymi już w końcu XIX w. i w początkach wieku XX przez W. W. Dokuczajewa, G.A. Kożewnikowa, I.P. Borodina, W.N. Sukaczewa i innych wybitnych uczonych, rezerwaty powołano jako wzorce przyrody wyznaczone na podstawie oceny krajobrazowo-geograficznej, przy czym ich główną zasadą jest brak ingerencji człowieka w środowisko naturalne.

Skoncentrowanie uwagi na powoływaniu rezerwatów skutkowało niedostatecznym rozwojem obszarów, na których możliwa byłaby organizacja turystyki przyrodniczej. Brak ten z jednej strony, i niewykorzystywane gospodarczo ogromne przestrzenie $z$ drugiej strony doprowadzily do powstania swoistego dla Związku Radzieckiego i Rosji zjawiska turystyki indywidualnej.

We współczesnej Rosji wektor rozwoju i powstawania sieci obszarów ochrony przyrody uległ odwróceniu. Każdego roku powoływane są nowe parki narodowe, których jedną z głównych funkcji jest organizacja wypoczynku. Jednakże niemożliwym jest pokonanie tradycji utrwalonych w ciągu 100 lat istnienia turystyki amatorskiej. Na obszarze państwa i krajów 
sąsiedzkich, niezależnie od aktualnego statusu ochrony danego terytorium, wyznaczono tysiące szlaków turystycznych.

W artykule przedstawiono funkcjonujące w Rosji pojęcia turystyki amatorskiej, aktywnej i sportowej, zaprezentowano charakterystykę aktualnego stanu turystyki aktywnej, rozpatrzono kwestię jej racjonalnej organizacji przestrzennej na obszarze Uralu i Kraju Permskiego.

\section{TURYSTYKA PRZYRODNICZA AKTYWNA I SPORTOWA - ZALEŻNOŚCI POJĘĆ}

W celu wyjaśnienia przytoczonych pojęć konieczne jest przekazanie informacji retrospektywnej. W czasach Związku Radzieckiego turystyka pod względem organizacji dzieliła się na planową i indywidualną (niezależną). Za turystykę planową przyjęto uważać takie podróże, które odbywane są zgodnie z przygotowanymi przez organizacje turystyczne programami, z uprzednio opłaconymi (podczas zakupu imprezy) i gwarantowanymi usługami (nocleg, wyżywienie, wycieczki itp.). Na zaplanowanych wyjazdach z aktywnymi sposobami przemieszczania się (pieszo, na kajakach, katamaranach, na nartach, konno) turyści podróżują wyznaczonymi szlakami z doświadczonym instruktorem. We współczesnych realiach ta forma odnosi się do turystyki komercyjnej, która organizowana jest przez touroperatorów. Jako przeciwwaga dla planowej istniała turystyka indywidualna.

Turystyka indywidualna to podróże po trasach, które opracowują sami turyści albo po tych, które rekomendowane są przez kluby turystów. W turystyce indywidualnej istniał podział na masową turystykę indywidualną i sportową turystykę indywidualną.

W Rosji pojmowanie turystyki sportowej jest swoiste, różniące się od powszechnie przyjętego poza jej granicami. Turystyka sportowa w Rosji to od 1949 r. dyscyplina sportowa, w której odbywają się zawody na różnych poziomach; istnieją liczne kategorie sportowe i tytuły. Wydzielone są w niej dwa klasyczne kierunki - wyprawy sportowe i sportowy turystyczny wielobój. Wielobój to zawody organizowane w zakresie określonej formy turystyki. Drużyna sportowców powinna pokonać konkretny dystans $\mathrm{z}$ szeregiem przeszkód najbardziej typowych dla danej dyscypliny. Należy przebiec jak najszybciej, przestrzegając zasad bezpieczeństwa, nie popełnić żadnych błędów i nie stracić ekwipunku. Zwykle, w większości form turystyki sportowej, dystans ten pokonuje się w ciągu godziny. Odległości są na różnych poziomach trudności. Po zakończeniu zawodów przyznaje się tytuły w różnych kategoriach.
Wyprawy sportowe organizowane są w sześciu kategoriach trudności. Ich istotą jest przemierzenie trasy w nienaruszonym środowisku naturalnym, z pokonywaniem przeszkód i przy zachowaniu maksymalnego stopnia bezpieczeństwa. Wyznaczono dziesięć form turystyki sportowej: piesza, górska, narciarska, wodna, speleoturystyka, rowerowa, samochodowa, motocyklowa (mogą w niej uczestniczyć sportowcy na quadach i na skuterach śnieżnych), żeglarska i konna. Minimalny czas trwania wypraw pierwszej kategorii trudności to sześć dni, zaś szóstej - 20 dni. Są to normatywy dotyczące minimalnej liczby dni, górne granice nie są określone.

Turystyka sportowa jest turystyką zorganizowaną, ale niekomercyjną. W celu przygotowania wyprawy sportowej należy przedłożyć odpowiednie dokumenty w komisji kwalifikującej, a po odbyciu podróży napisać sprawozdanie w specjalnej formie, które powinna przyjąć ta sama komisja. Dopiero wtedy możliwe jest włączenie danej trasy do jakichkolwiek zawodów i otrzymanie kategorii. W sprawozdaniu określa się doświadczenie, które nabywają uczestnicy podróży, jest ono niezbędne, żeby wyruszyć następnym razem na trudniejszą trasę. W Rosji istnieje ogólnopaństwowa organizacja - Federacja Turystyki Sportowej Rosji (FTSR), której podlegają oddziały regionalne. Do regionalnych federacji należą różne kluby turystów, związki, sekcje i inne organizacje.

Początków współczesnej turystyki aktywnej doszukiwać się należy w amatorskiej turystyce masowej ubiegłego stulecia. Pod pojęciem turystyki aktywnej przyjęło się rozumieć podróże w nieprzekształconym przez człowieka środowisku naturalnym, podczas których dominują aktywne sposoby przemieszczania się. Także tutaj wydziela się szereg form turystyki, takie jak np.: wodna, piesza, speleoturystyka, rowerowa, żeglarska.

Turystyka sportowa i aktywna mają wspólne podstawy, ale różnią się pod względem swoich celów i sposobów ich realizacji. Turystyczne wyprawy sportowe mają konkretny sportowy cel, na osiągnięcie którego zużywane są siły grupy. Dotyczy to w szczególności tras wyższych kategorii trudności. Dla turystyki sportowej trasy I, II i kolejnych kategorii trudności są stopniami prowadzącymi ku bardziej złożonym marszrutom. Wraz z osiagganiem mistrzostwa sportowego turyści zdobywają coraz bardziej skomplikowane szlaki i rejony. Zwieńczeniem tej „wspinaczki” są trasy wyższej kategorii trudności i wyznaczanie nowych, dotąd nieprzebytych (MYSZLAWCEWA 2007). Turystyka sportowa nie jest masowa. Szacuje się, że w Rosji uprawia ją kilkaset tysięcy osób, a w Kraju Permskim, który jest trzecim w Rosji pod względem jej rozwoju - do 10 tys. osób.

W turystyce aktywnej pierwszeństwo oddaje się trasom nieklasyfikowanym, nieskategoryzowanym lub 
łatwiejszym kategoriom sportowym (I, II, III). Pod względem organizacyjnym mogą to być zarówno wyjazdy przygotowane samodzielnie przez turystów, jak i przez touroperatorów. Programy podróży aktywnych są opracowywane na podstawie informatorów, klasyfikatorów i przewodników turystyki indywidualnej wydanych w okresie jej rozkwitu. Ta forma ma charakter bardziej masowy. Określenie wielkości ruchu turystycznego turystów aktywnych jest wyjątkowo trudne, gdyż oficjalne statystyki takich danych nie prezentują.

Podsumowując ogólne zagadnienia dotyczące przyrodniczej turystyki aktywnej i sportowej można stwierdzić, że głównym walorem, zarówno w przypadku turystyki sportowej, jak i aktywnej, jest dzika przyroda, obie formy są zależne od warunków naturalnych, różnią się jednak specyfiką i właściwymi sobie cechami organizacji przestrzennej.

\section{URAL JAKO DESTYNACJA TURYSTYCZNA}

W rozumieniu przyrodniczym za Ural uważa się terytorium ciągnące się południkowo przez ponad 2 tys. km od brzegów Morza Karskiego do środkowoazjatyckich stepów i półpustyń. Ural jest wyraźnie wyodrębniony w przestrzeni jako region górzysty, otoczony od zachodu i wschodu równinnymi nizinami - Wschodnioeuropejską i Zachodniosyberyjską.

Pomimo to że góry Ural leżą wewnątrz kontynentu i są odległe od terenów nadmorskich, nie są zbyt wysokie, nie mają takich walorów jak wulkany i gejzery, oddalone są od stolic i granic państw, są wyraźnie wyodrębnionym regionem turystycznym w Rosji, a w przyszłości będą jednym z najważniejszych regionów turystycznych świata. Ural sensu largo, jako góry Ural wraz z przylegającymi obszarami, nasycony jest osobliwościami przyrodniczymi. W związku z tym w ciągu kilku dziesięcioleci ukształtował się tu pas regionów turystyki aktywnej, gdzie koncentrują się różnorodne szlaki turystyczne - przede wszystkim związane $\mathrm{z}$ formami turystyki opartymi na środowisku naturalnym (ZYRIANOW, KOROLIOW 2009). Wzorcowe szlaki odmiennych kategorii trudności dla różnych form turystyki są opracowywane i od dłuższego czasu wykorzystywane na Uralu (ZYRIANOW, KOROLIOW 2008).

Góry Ural i otaczające je pasy Prieduralja i Zauralja $\mathrm{w}$ okresie rozwoju masowej turystyki amatorskiej w ZSRR można było uważać za „kraj turystyczny”. Liczni turyści próbowali pokonać je na jak najdłuższym odcinku, a nawet całościowo $\mathrm{z}$ północy na południe lub odwrotnie. Niemało śmiałków dokonywało tego podczas pojedynczej długiej wyprawy - jednej ekspe- dycji. Najczęściej turyści odwiedzają jeden rejon gór Ural za drugim. Będąc na wyprawie w Uralu Środkowym, wybierają się następnie w Południowy, Północny, a potem w Pripolarnyj i Polarnyj. Szczególnie wielu turystów próbuje odwiedzić także uralskie przedłużenia ku północy - grzbiet Paj-Choj i ku południowi - góry Mugodżary w Kazachstanie. W Jekaterynburgu istniał nawet klub, do którego należeli ci, którzy przeszli wzdłuż wszystkich gór Uralu, a te ciągną się na dystansie ponad $2000 \mathrm{~km}$.

Wiele wykorzystywanych szlaków turystycznych poprowadzono również w poprzek Uralu, wykorzystując fakt, iż łańcuch ten nie jest szeroki. Z obu stron gór w południowej ich części leżą obszary zamieszkałe, a przecinające je szlaki mają często charakter łączników międzyregionalnych.

Biorąc pod uwagę możliwości i rolę $\mathrm{w}$ turystyce dużych powierzchniowo krajów, Ural można porównać do Sierra Nevada i Gór Skalistych (w zachodniej części USA). W USA w górach Sierra Nevada istniejący system obszarów chronionych o profilu turystycznym ma formę zwartego pasa. Specyfika terenów chronionych na Uralu jest inna. Stworzone w ubiegłym stuleciu rezerwaty - Wiszerski i Basegi w Kraju Permskim, Dienieżkin kamien' w obwodzie swierdłowskim, Baszkirski w Republice Baszkirii - stały się barierą dla rozwoju turystyki na tym obszarze, przeszkodami na niekiedy jedynych istniejących szlakach.

Góry Ural zajmują około 1/4 powierzchni Kraju Permskiego, jego północny wschód, a wraz z podgórskim pasem Prieduralja - około połowy obszaru. Ural i Prieduralje to najbardziej atrakcyjny region turystyczny Kraju Permskiego.

\section{ZAKRES PRZESTRZENNY TURYSTYKI AKTYWNEJ W KRAJU PERMSKIM}

Największe przyrodnicze walory turystyczne Kraju Permskiego związane są z bogactwem rzek, a także krajobrazami górskimi i leśnymi.

Wschód Kraju to główny region rozwoju turystyki wodnej związanej z występującymi tu rzekami. Tradycje wiosennego i letniego spływu turystycznego sa na tym obszarze bardzo silne. Wiszera, Bieriozowaja, Jajwa z Czan'wą, Czusowaja, Us'wa i Syłwa - to najpopularniejsze rzeki do organizacji turystyki wodnej. $\mathrm{Na}$ wymienionych rzekach urządza się dużą liczbę komercyjnych podróży, w szczególności w okresie letnim. Tłumaczyć to należy dobrą dostępnością komunikacyjną punktów początkowych i końcowych tras, a także wysokimi walorami krajobrazowymi permskich rzek. Ponadto w Kraju Permskim bardzo popularny jest majowy spływ przy wysokim stanie wód - tylko wówczas większość rzek w Uralu Środkowym 
i Północnym możliwa jest do pokonania. Jednocześnie stają się wtedy trudniejsze do przebycia, ich kategoria staje się drugą, na niektórych odcinkach nawet z elementami trzeciej. Najbardziej popularne podczas sportowego majowego spływu rzeki to Us'wa, Wilwa, Wiżaj i Kojwa. Nie stanowi problemu dostanie się do początku szlaków tymi rzekami, jak również opuszczenie ich. Sam spływ trwa kilka dni, a czas przejazdu do centrum kraju, do punktu startowego, wynosi tylko kilka godzin. W okresie wiosennym rzekami podróżują głównie turyści amatorscy, niezorganizowani, zaś liczba grup zorganizowanych jest nieznaczna. Ogółem ruch turystyczny szacowany jest na kilka tysięcy osób na każdą rzekę w ciągu pierwszych 10 dni maja.

Permska część gór Ural - to region podróży pieszych, które od niedawna uznać można za masowe. Głównymi walorami przyrodniczymi terytorium Uralu Północnego i Środkowego w Kraju Permskim są góry z różnorodną rzeźbą terenu. Występują tu wyraziste formy (szczyty, skały, wychodnie skał pierwotnych), a także łagodne zrównania. Dla Uralu Północnego typowe są spłaszczone grzbiety, stare powierzchnie zrównań. Takie ukształtowanie terenu jest korzystne dla pieszych wypraw po górach. Trasa po grzbiecie Choza-Tump to klasyka szlaku turystycznego w Uralu Północnym.

Najbardziej dostępne i najczęściej odwiedzane obszary, na których organizowane są wycieczki piesze, to uroczysko Kamienne Miasto położone na grzbiecie Rudianyj Spoj w regionie griemiaczinskim i skała Jermak w regionie kungurskim. Dłuższe szlaki turystyczne wyznaczono na przypominającym płaskowyż grzbiecie Kwarkusz (maksymalna wysokość 1066 m n.p.m.), gdzie można spotkać dzikie renifery tundrowe. Znaczącym walorem przyrodniczym Kwarkusza jest Wodospad Żygałanski, położony na rzece o tej samej nazwie. Popularny jest także szlak na grzbiet Czuwalski kamien', położony na granicy rezerwatu Wiszerskiego, grzbiet Oslanka (1119 m n.p.m.) - najwyższy szczyt Uralu Środkowego.

Niezwykle interesujące i najtrudniej dostępne walory turystyczne Kraju Permskiego znajdują się na terenie rezerwatu Wiszerskiego, który jest obszarem typowo górskim. Tu rozciąga się grzbiet Tułymski Kamien', najwyższy w kraju (1469 m n.p.m.), grzbiet Iszerim, Murawjinyj Kamien', Munintump, Sakłaimsoriczachl i inne. Ze względu na ścisłą ochronę rezerwatu, możliwości jego zwiedzania są reglamentowane.

Speleoturystyka w Kraju Permskim nie jest w takim stopniu umasowiona jak turystyka wodna. W Kraju Permskim znajduje się ponad 700 jaskiń, a jego wizytówką mogą być cztery główne. Najdłuższa jaskinia Uralu, która częściowo zalana jest wodą, to Ordinskaja (5200 m), najtrudniejsza jaskinia Kraju Tiomnaja (kategoria trudności 3B), najdłuższa jaskinia
Kraju Permskiego - Diwja, o długości ponad 10 km, i najczęściej odwiedzana i jedyna na świecie jaskinia w gipsach, w której organizowana jest obsługa wycieczek - Kungurskaja Ledianaja (odwiedzana jest rocznie przez 120 tys. osób).

Oprócz wymienionych jest jeszcze wiele bardzo popularnych i mających dobrą dostępność komunikacyjną dużych jaskiń: Rossijskaja, Gieołogow 1, 2 i 3, Paszyjskaja, Kiziełowskaja, Czudiesnica, Czan'winskaja, Kimczmienskaja, Zujatskaja, Oktiabr'skije, Tajn i inne. Można je zwykle pokonać w jeden dzień, dzięki czemu są masowo odwiedzane $\mathrm{w}$ dni wolne. Warto podkreślić, że najlepszym sezonem do eksploracji jaskiń jest okres od listopada do marca, kiedy poziom wód gruntowych jest najniższy, a groty są stosunkowo suche. W jaskiniach Kraju Permskiego, oprócz Kungurskiej i Ordinskiej, w których rozwija się nurkowanie jaskiniowe, nie ma organizowanych komercyjnych tras turystycznych. Odwiedzane są tylko przez turystów indywidualnych i amatorskich, zaś ogólna liczba turystów niezorganizowanych we wszystkich jaskiniach sięga kilku tysięcy w ciągu roku.

\section{ORGANIZACJA TURYSTYKI AKTYWNEJ A OCHRONA PRZYRODY - KONFLIKTY PRIORYTETÓW}

W granicach Uralu w ciągu ponad siedmiu dekad powstał system szlaków turystycznych odpowiednich dla turystyki aktywnej. Największa ich koncentracja zauważalna jest $\mathrm{w}$ uralskim regionie górskim na peryferiach takich jednostek administracyjnych, jak Kraj Permski i obwód swierdłowski, obwód czelabinski i Baszkiria. Tam też od lat 30. XX w. tworzono obszary ochrony przyrody o różnym statusie. W przestrzeni te dwa zjawiska są sobie bliskie, co nieuchronnie prowadzi do pojawienia się konfliktów interesów między ochroną przyrody a organizacją wypoczynku. Zauważalne jest to szczególnie na tych obszarach chronionych, których status jest przyjęty, jednakże jego egzekwowanie jest słabo kontrolowane (dotyczy to np. pomników przyrody, obszarów chronionego krajobrazu, czasowych rezerwatów krajobrazu i innych). Najprostszym rozwiązaniem byłaby zmiana sieci szlaków turystycznych w celu zmniejszenia napływu turystów na wyjątkowo cenne przyrodniczo tereny. W praktyce wydaje się to nieosiągalne, na co składa się kilka przyczyn. Jedną z nich jest to, że sieć szlaków na danym terytorium była utworzona na długo przed przyjęciem statusu o ochronie przyrody. W konsekwencji tradycja turystyczna jest bardziej utrwalona. Druga przyczyną tak bliskiego koegzystowania tych zjawisk jest to, że ich wymagania wobec środowiska przyrodniczego są w wielu miejscach stycz- 
ne. Obszary chronione, szczególnie te o znacznych powierzchniach (np. rezerwaty), tworzone były w oparciu o kryteria krajobrazowo-geograficzne na najmniej naruszonych terytoriach. Już w początkowym okresie organizacji rezerwatu powstawały trudności z włączaniem do nich dużych obszarów - zgodnie z prawem, wydzielano je na słabo zagospodarowanych miejscach. Na takich też terenach, niewykorzystywanych gospodarczo, powstaje sieć szlaków turystycznych. Co więcej, trasy turystyczne poprowadzone są w miejscach o zróżnicowanym krajobrazie i z wyjątkowymi walorami przyrodniczymi.

W ten sposób najcenniejsze przyrodnicze obszary są pod silnym wpływem turystyki masowej. Negatywny wpływ turystyki dotyczy głównie zaśmiecania brzegów rzek nieczystościami organicznymi, wydeptywania pokrywy roślinnej w miejscach biwakowania, niekontrolowanego wyrębu lasu itp. Problem ten jest szczególnie zauważalny na obszarach o dobrej dostępności komunikacyjnej, co prowadzi do degradacji kompleksów przyrodniczych, ich dewaluacji i obniżenia atrakcyjności rekreacyjnej.

\section{WSPÓŁCZESNE ROZWIAZZANIA STOSOWANE W ZAGOSPODAROWANIU OBSZARÓW WYKORZYSTYWANYCH NA POTRZEBY TURYSTYKI AKTYWNEJ W KRAJU PERMSKIM}

Jak pokazuje praktyka, realizacja potrzeb turystycznych i rekreacyjnych przy jak najmniejszej szkodzie dla kompleksów przyrodniczych możliwa jest na niektórych terenach, takich jak parki narodowe i krajobrazowe. Te terytoria przygotowane są do obsługi turystyki masowej. Wydzielono na nich strefy funkcjonalne, w tym rekreacyjne i absolutnego spokoju, stworzono infrastrukturę niezbędną dla odwiedzających, w szczególności wytyczono szlaki, zagospodarowano miejsca odpoczynku, kempingi, zadbano o logistykę, nawigację itp. Parki narodowe i krajobrazowe stały się w XX w. w większości krajów świata formą skutecznie łączącą cele związane $z$ ochroną przyrody i organizacją turystyki.

W Rosji funkcjonuje ponad 40 parków narodowych. W obecnych realiach konieczne staje się zwiększenie ich liczby, szczególnie $\mathrm{w}$ tych regionach, gdzie silne są tradycje uprawiania turystyki związanej z wykorzystaniem walorów naturalnych. Zgodnie z koncepcją rozwoju systemu przyrodniczych obszarów chronionych o znaczeniu federalnym (Rasporiażenije... 2011), w Rosji planuje się stworzenie jeszcze 20 parków narodowych do 2020 r., lecz tylko jeden park utworzony zostanie w granicach Uralu (Park Naro- dowy Zigalga w obwodzie czelabińskim). Dzięki temu we wszystkich regionach Uralu, oprócz Kraju Permskiego, istnieć będą obszary chronione tej kategorii (tab. 1).

Tab. 1. Parki narodowe w regionach Uralu

\begin{tabular}{|c|l|l|c|}
\hline Lp. & \multicolumn{1}{|c|}{ Region } & Parki narodowe & $\begin{array}{c}\text { Rok } \\
\text { utwo- } \\
\text { rzenia }\end{array}$ \\
\hline 1 & Republika Komi & Jugyd-Wa & 1994 \\
\hline 2 & Obwód swierdłowski & Pripyszminskije bory & 1993 \\
\hline 3 & Kraj Permski & - & - \\
\hline 4 & Obwód czelabiński & Taganaj & 1991 \\
& & Ziuratkul & 1993 \\
& & Zigalga & 2014 \\
\hline 5 & Baszkiria & Baszkiria & 1986 \\
\hline
\end{tabular}

Źródło: opracowanie własne.

O konieczności stworzenia parku narodowego w Kraju Permskim wypowiadali się liczni uczeni oraz aktywiści, którzy wskazywali na różne obszary godne tej formy ochrony, jak np. dolina rzeki Syłwy w dół biegu od miasta Kungur (AKIMOW, AFANASJEWA, STIENNO 1996) czy grzbiet Kwarkusz (KOROLIOW 2012).

Kwestia ta nie została rozstrzygnięta pozytywnie, jednakże wyznaczenie takiego obszaru jest konieczne i uwarunkowane wysokim stopniem wykorzystania na potrzeby rekreacji unikatowych i typowych dla regionu kompleksów naturalnych, co prowadzi do ich degradacji. Istnieje realne ryzyko utraty obiektów dziedzictwa przyrodniczego Kraju Permskiego. Przy braku możliwości utworzenia parku narodowego - obszaru podlegającego władzy federalnej, jako rozwiązanie alternatywne sugerowane jest wytyczenie parku krajobrazowego - obszaru chronionego podlegającego władzy regionalnej, który łączyłby w sobie funkcje ochrony przyrody i rozwoju turystyki (BUZMAKOW, ZAJCEW, SANNIKOW).

Wybór miejsc, na których powstać by mogły nowe obszary chronione, jest trudnym zadaniem. Specjaliści uważają, że przy powoływaniu parku krajobrazowego konieczne jest wzięcie pod uwagę potencjału naturalnego i specyfiki współczesnego wykorzystania przyrodniczego terenu, obecnych czynników antropopresji na środowisko naturalne. Najnowsze badania pokazują, że te ostatnie wynikają głównie z wykorzystania walorów przyrodniczych w celach rekreacyjnych. Degradacja spowodowana tym działaniem zauważalna jest na licznych obszarach chronionych, położonych w różnych częściach Kraju Permskiego. Jedną z przyczyn popularności rekreacji na takich obszarach w Prikamju, jest brak parków krajobrazowych, zadaniami których byłoby nie tylko zachowanie środowiska przyrodniczego, ale i zagwarantowanie możliwości wypoczynku. Utworzenie terenów chronionych tej 
kategorii, przy wykorzystaniu sieci już istniejących, pozwoliłoby uporządkować i zoptymalizować działania rekreacyjne przy jednoczesnym zachowaniu typowych unikatowych i szczególnie cennych walorów przyrodniczych.

Stworzenie parku krajobrazowego, wraz z chroniącym naturę zagospodarowaniem i wykwalifikowaną kadrą (ochrona, osoby odpowiedzialne za łączność, komunikację, służby medyczne i edukacji ekologicznej), pozwoli zahamować degradację ekosystemów, zniwelować ryzyko utraty zdrowia, doprowadzi do wzrostu kultury ekologicznej odwiedzających.

Sugerowanym obszarem, który można objąć ochroną jako park krajobrazowy, jest dolina rzeki Us'wy w jej środkowym biegu (od miejscowości Szumichinski do Mys) i przylegające do niej terytoria. Przemawiaja za tym liczne argumenty. Według oceny specjalistów z zakresu turystyki (CHUDIEN'KICH 2006), teren ten ma znaczny potencjał turystyczno-rekreacyjny, sprzyjający rozwojowi form turystyki aktywnej wykorzystujących walory naturalne, takie jak turystyka wodna (spływy na łodziach wiosłowych i pontonach), piesza (obozy wędrowne i piesze wycieczki), wspinaczka skałkowa i lodowa, speleoturystyka, narciarstwo itp.

Analizowany teren charakteryzuje się dobrą dostępnością komunikacyjną. Najbliższe miasta, Griemiaczinsk i Czysowoj, położone są 15 i $60 \mathrm{~km}$ od miejscowości Us'wa. Odległość od Permu, skąd napływa większość turystów, wynosi 190 km, do Bieriezniki jest 125 km. Miejscowość Us'wa, która znajduje się na drodze krajowej Kungur-Solikamska, może pełnić funkcję bramy do projektowanego parku. Przebiega tędy też linia kolejowa Czusowoj-Solikamsk. Część znaczących atrakcji turystycznych dostępna jest dzięki drogom kołowym będącym pod kontrolą organów władzy miejscowej (trasa od drogi Kungur-Salikamsk do miejscowości Jubilejnyj, trasa Jubilejnyj-Biezgodowo $\mathrm{w}$ regionie griemiaczinskim, droga W. KalinoMys w regionie czusowskim).

Wykorzystanie regionu na potrzeby turystyki ma długie tradycje, do czego przyczyniły się liczne fakty. Rzeka Us'wa jest dobrze znana w Kraju Permskim i poza jego granicami jako idealne miejsce do organizowania spływów rodzinnych. Łatwość jej pokonania, dobra dostępność komunikacyjna, piękno krajobrazów górskiej tajgi na granicy Europy i Azji, przybrzeżne skały Us'winskije Stołby sprawiają, że jest jedną z najbardziej atrakcyjnych spławnych rzek. Szlaki turystyczne po Us'wie opisywano w przewodnikach w 2. poł. XX w. Obecnie szlak wodny na Us'wie (od miejscowości Us'wa do Mys) jest jednym z najczęściej uczęszczanych podczas dni wolnych w okresie letnim.

Unikatowymi walorami krajobrazowymi Uralu Środkowego są skalne labirynty upiększające liczne szczyty pokrytych lasami gór. Są to tzw. kamienne miasta lub diabelskie grodziska. Jedno z najbardziej malowniczych skalnych miast znajduje się na grzbiecie Rudianskij Spoj, w pobliżu miejscowości Us'wa. Kamienne ostańce wzdłuż Us'wy, a także diabelskie grodziska są popularnymi miejscami wypoczynku i treningu dla turystów, alpinistów, wspinaczy i wypoczywających.

$\mathrm{Na}$ analizowanym obszarze występują licznie jaskinie. W granicach projektowanego parku krajobrazowego znajduje się ich ponad 10. Są to jaskinie Gieołogow 1, 2, 3, Pierwomajskaja, Riebristaja, Dinamitnaja, Us'winskaja ledianaja, Wysockogo, Us'winskaja-1, Us'wa-Ugolnaja, Us'winskaja miedwieżja. Tu właśnie znajdują się najbardziej charakterystyczne przekroje geologiczne okresu permskiego. Wszystkie jaskinie są często odwiedzane przez speleologów.

Sama miejscowość Us' wa leży w granicach Gornozawodskogo Prikamja - jednego z regionów Uralu Gornozawodskogo, z pasem miast i miejscowości, których powstaniu sprzyjało wydobycie różnych surowców mineralnych. Stały się one pierwowzorami dla miejscowości opisanych przez Bażowa w historiach o pani Górze Miedzianej, bajkach o szkatułce z malachitu.

Współcześnie górnicze regiony Kraju Permskiego nie są związane z produkcją, lecz ukierunkowane są na rozwój narciarstwa wysokogórskiego. Znaczne różnice wysokości (do 200-300 m), dobra infrastruktura, pokrywa śnieżna i duży popyt sprzyjają rozwojowi tego rodzaju działalności w górach Uralu Środkowego. Na opisywanym terenie są przesłanki przyrodnicze i społeczno-ekonomiczne do rozwoju tego rodzaju aktywności gospodarczej.

Tutaj, na stosunkowo zwartym obszarze o powierzchni 26,5 tys. ha, zlokalizowanych jest kilka obszarów chronionych o znaczeniu regionalnym - pomniki przyrody Stołby, Bolszoje Briewno, Ponoramnaja Skała, Poworotnyj Łog, Omutnoj Kamien', Suchoj Łog, Kamiennyj Gorod. W każdym z nich ruch turystyczny jest znaczny.

W podsumowaniu należy stwierdzić, że wszystkie atrakcyjne obiekty obszaru w różnym stopniu przyciągają turystów. Najczęściej odwiedzane są: Kamiennyj Gorod, Us'winskije Stołby, szlak wodny na rzece Us'wa, uroczysko Suchoj Łog. Według oceny ekspertów liczba turystów sięga 8 tys. osób, a sezonowość odwiedzin jest łatwo zauważalna. Szczyt przypada na dni wolne $\mathrm{w}$ okresie od lipca do września. W dni „niepracujące” we wrześniu w Kamiennym Gorodie może jednocześnie przebywać ponad 200 osób. W celu doprecyzowania danych dotyczących wielkości oraz sezonowości ruchu turystycznego konieczne jest przeprowadzenie specjalnych badań.

Speleoturystyka nie ma tak masowego charakteru. Jednakże groty także są ważnymi obiektami służą- 
cymi rekreacji. Najczęściej odwiedzane są jaskinie Suchogo Łoga (Gieołogow 1, 2, 3, Riebristaja).

Obecnie przyjazdy są żywiołowe, niekontrolowane, co prowadzi do degradacji środowiska naturalnego. W związku z tym jednym z ważniejszych celów działań związanych $\mathrm{z}$ utworzeniem nowego parku krajobrazowego jest określenie maksymalnej chłonności turystycznej ekosystemów. Jest to zadanie, które musi być wykonane.

Efektywną metodą troski o środowisko naturalne, według autorów, jest stworzenie dużego powierzchniowo obszaru ochrony przyrody o znaczeniu regionalnym. Nadanie terytorium nowego statusu pozwoli na przeprowadzenie niezbędnych prac związanych z jego zagospodarowaniem i uczyni możliwym regulację i zarządzanie ruchem turystycznym. Zaleca się, by dla zachowania równowagi ekologicznej opracować propozycje zagospodarowania terenu parku krajobrazowego tak, by przygotować go na przyjęcie turystów.

\section{Z języka rosyjskiego tłumaczyła:} Armina Kapusta

\section{BIBLIOGRAFIA}

AKIMOW W.A., AFANASJEWA L.I., STIENNO S.P., 1996, Obosnowanije celesoobraznosti organizacyi nacyonalnogo parka "Sytwinskij", Trudy Mieżd. naucz. konf., 2: Ekotogija, Perm', s. 214-215.

BUZMAKOW S.A., ZAJCEW A.A., SANNIKOW P.Ju., Wyjawlenije tierritorij pierspiektiwnych dla sozdanija prirodnogo parka w Piermskom kraje, „Izwiestija Samarskogo naucznogo centra RAN”, 13, 116, s. 1492-1495.

CHUDIEN'KICH Ju.A., 2006, Turizm w Piermskom kraje: tierritorialnaja organizacyja $i$ riegionalnoje razwitije, Pierm. gos. un-t., Pierm', ss. 191.

KOROLIOW A.Ju., 2012, Obosnowanije sozdanija nacionalnogo parka "Chriebiet Kwarkusz" na tierritorii Kracnowiszerskogo rajona Piermskogo kraja, „Gieograficzeskij wiestnik”, 1 (20), s. 99-105.

MYSZLAWCEWA S.E., 2007, Aktiwnyj turizm w riegionach Urała (marszrutnyj princyp tierritopialnoj organizacyi), awtoref. dissier. na soiskanije stiepieni kandydata geiogr. nauk, Pierm'.

Rasporiażenije Prawitielstwa Rossijsskoj Fiedieracyi ot 22 diekabria 2011 g. N 2322-r, g. Moskwa „Koncepcyja koncepcyi razwitija sistiemy osobo ochraniajemych prirodnych tierritorij fiedieralnogo znaczenija w RA na pieriod do $2010 \mathrm{~g} . "$.

ZYRIANOW A.I., KOROLIOW A.Ju., 2008, Etatonnyje turistskije marszruty: gieograficzeskij aspiekt, „Wiestnik nacyonalnoj akadiemii turizma", SPB, 4, s. 53-57.

ZYRIANOW A.I., KOROLIOW A.Ju., 2009, Turistskoje rajonirowanije gornych tierritorij, „Izwiestija MGU”, 6, Moskwa, s. 19-25. 